\title{
The Distribution of Buceros rhinoceros and Awareness of Its Conservation Status
}

\author{
J. Mohd-Azlan, Abas Said, Sim Lee Kheng, and Oswald Braken Tisen
}

\begin{abstract}
A rapid survey on the distribution of hornbills in Santubong National Park, Sarawak, East Malaysia, was carried out in April 2013 using point sampling technique at various locations around the park. Only the Rhinoceros hornbill, Buceros rhinoceros, was recorded, with a total of 45 independent calls and 15 observations at 10 locations around the protected area, mostly during early mornings and late evenings from $162 \mathrm{~h}$ of survey. Most of Rhinoceros hornbills were observed in pairs $(73 \%)$, while a single observation recorded at least ten individuals at a location. Additionally, local communities were interviewed to collect information on the occurrence, status, ecology and perception on Hornbill conservation in Santubong National Park. A standard questionnaire was designed to meet the purpose of this study. This survey was conducted on local communities from five local villages around Santubong National Park, local and international tourist visiting touristic areas in Santubong peninsula. In general the awareness on the conservation needs and status of the hornbill is high suggesting that the communities are interested and supportive of conservation related activities. Based on the socio-economic and ecological survey, the surrounding habitat of this protected area need to be protected through park extension that will increase connectivity between nearby forest patches which in turn may ensure the long term viability of the Rhinoceros hornbill in Santubong National Park.
\end{abstract}

\footnotetext{
J. Mohd-Azlan (殴

Department of Zoology, Faculty of Resource Science and Technology,

Universiti Malaysia Sarawak, 94300 Kota Samarahan, Sarawak, Malaysia

e-mail: azlan@frst.unimas.my
}
A. Said
Department of Plant Science and Environmental Ecology, Faculty of Resource Science and Technology, Universiti Malaysia Sarawak, 94300 Kota Samarahan, Sarawak, Malaysia
S.L. Kheng • O.B. Tisen
Biodiversity Conservation Department, Protected Areas \& Biodiversity Conservation, Sarawak Forestry Corporation, Lot 218, KCLD, Jalan Tapang, Kota Sentosa, 93250 Kuching, Sarawak, Malaysia 